DOI 10.15290/cnisk.2018.01.04.07

DOC. DR ALESYA KORSAK

orcid.org/0000-0003-1634-3721

Połocki Uniwersytet Państwowy

\title{
Społeczne i polityczne życie BSSR w czasopiśmie „Bielaruskaja Rabotnitsa i Syalyanka” („Białoruska Robotnica i Chłopka”) 1924-1939
}

\section{Streszczenie}

W tym artykule na przykładzie kobiecego czasopisma „Bielaruskaja Rabotnitsa i Syalyanka” („Białoruska Robotnica i Chłopka”) badany jest proces odzwierciedlający społeczno-polityczne życie BSSR na łamach czasopism drukowanych. Korelacja chronologiczna między data ustanowienia magazynu i pierwszego wydania publikacji w 1924 r. a końcową datą 1939 r. w międzynarodowym kontekście odpowiada początkowi II wojny światowej i zjednoczeniu Zachodniej Białorusi z BSSR. Przeanalizowano ponad 90 numerów $z$ różnych lat adekwatnych tematycznie.

Analiza treści informacji magazynu „Białoruska Robotnica i Chłopka" wykazała, że w latach 1924-1939 redakcja magazynu zmieniała swoja koncepcję w podejściu do pokazywania życia społecznego i politycznego, jak również ukazywania roli kobiet, w zależności od sytuacji wewnętrznej i zewnętrznej - od kolektywizacji i industrializacji, likwidacji analfabetyzmu i polityki represyjnej do retoryki wojskowej związanej ze wzmocnieniem nazistowskich Niemiec i faszystowskiego bloku w latach 1933-1939.

Słowa kluczowe: „Bielaruskaja Rabotnitsa i Syalyanka”, życie społeczne i polityczne, BSSR, propaganda 


\title{
SOCIAL AND POLITICAL LIFE IN THE BSSR AS PRESENTED IN THE "BYELORUSSIAN WORKER AND PEASANT WOMAN" MAGAZINE (BIELARUSKAJA RABOTNITSA I SYALYANKA) 1924-1939
}

\begin{abstract}
The following article examines the process of reflecting the socio-political life in the BSSR presented in periodicals on the example of the women's magazine "Byelarusian Worker and Peasant Woman". The publishing dates of the first and the last issue of the magazine - 1924 and 1939 - correspond to the outbreak of World War II and the reunification of Western Belarus with the BSSR. More than 90 issues of the magazine are analyzed in the article selected according to the topic-oriented content.

The analysis of the content of the "Byelarusian Worker and Peasant Woman" magazine showed that, in the period 1924-1939, the editorial board of the magazine changed its approach to depicting and commenting on public and political life, as well as shaping the role of women in both spheres, from collectivization and industrialization, elimination of illiteracy and repressive policies to the military rhetoric connected with the strengthening of the Nazi Germany and fascist blocks in the years 1933-1939.

Keywords: "Byelarusian Worker and Peasant Woman", social and political life, BSSR, propaganda

Mass media and propaganda have always influenced the process of shaping person's worldview. One of the most important features of mass media is complementarity and complexity of its influence. It acts as an element of a whole system of ideological, educational and propaganda activity.

Women oriented print media used to be a sort of guide for carrying out the process of development of the new Soviet daily routine, moreover, it was devoted to play an essential role in the formation of a new way of life, along with the new Soviet identity. An important trend in the concept of gender equality was connected with the ideology, which developed new behaviour patterns and moral values in public consciousness through agitation and propaganda activity. An essential aspect of the formation of the new Soviet woman used to be a process of struggling with backwardness, which included not only the struggle with illiteracy, inactivity
\end{abstract}


of women in social life and their religiousness, but also, and mostly, the development of women's social and political activity and consciousness and by the way the development of the Party's course support. The influence of ideological propaganda of the new Soviet person was decisive in the development of new gender stereotypes and new values in family and daily routine as well as in profession. Women were also engaged in the flow of social and political, economic and social changes through the periodical press ${ }^{1}$.

During the period under research, a whole network of mass workers, peasants, youth and children's editions was created in the Republic. Since 192542 newspapers (one-time circulation is 200 hundreds of copies) and 43 magazines (one-time circulation is 200 hundreds of copies) were edited. At this time, the press was focused on the problems of preparing the conditions for the successful building of socialism. The issues of overcoming economic ruin, strengthening of labor discipline, propaganda and explanation of the Party's new economic policy used to occupy a significant place, the materials on the socialist restructuring of agriculture, expansion of cooperation, especially in production, used to be published.

The press actively pursued the elimination of unemployment and illiteracy, acceleration of the construction of schools and kindergartens and cultural and educational institutions. There were materials aimed at strengthening the unity of the Party, at eliminating the enemy activities of nationalists, the trotskist opposition and other anti-Party groups ${ }^{2}$. "Press", according to the name of one of the articles, dated 1930, is a common propagandist and collector of working people in the socialist building. Consequently, newspapers and magazines were the most effective form of information transmission in terms of propaganda at that time. As women in 1920-1930 became to be more actively engaged in social and political life, women oriented press naturally appeared. Masses of working and peasant women should see how our magazine meets

1 J.A. Kostenko, Żenskoje dviżenije $w$ Rossiji w 1920-1930 gg. Avtoreferat na soiskanije stepeni kandidata istoricheskih nauk, Moskwa 2006, s. 22-23.

2 Peryjadyczny druk Bielarusi, red. W.S. Adamowicz [et. al.] [w:] Bielaruskaja sawetskaja encyklapedyja, Minsk 1981, s. 19. 
their requirements, how it gathers them around the mission of the socialist building ${ }^{3}$.

Based on this, in 1924 the women magazine „Bielaruskaja Rabotnitsa i Syalyanka" started to be issued in Minsk in Belarusian language. Some of the articles, which concern all-union normative documents were printed in Russian. In 1931-1941 the magazine was edited under the name „Rabotnitsa i Kalhasnica Bielarusi”" .

But the women oriented press didn't appear by accident. For solving women's problems special structures started to be launched - Women units, the first of which was launched in 1919. It was called Women's Unit of the Central Committee of Russian Communist Party of bolsheviks and was headed by famous Inessa Armand. The same structures were launched in all the Union Republics, one of their tasks was the edition of the magazine for women ${ }^{5}$.

According to the R. Meleshevich's opinion, the women unit in Belarus, as well as in Russia, first used to function as an attachment to the Party, to execute the leaders' will and the Party's directions ${ }^{6}$. According to the statement of the General Secretary of the Central Committee of Communist Party of Bolsheviks in Belarus Gamarnik in 1929 Women units, created in 1919, carry out work towards the organisation of working women, identify and register their activity, engage them into struggling for Soviets and socialist building ${ }^{7}$.

The activity of the magazine „Bielaruskaja Rabotnitsa i Syalyanka" can be divided into several stages. One of the first stage is formation, which chronologically almost coincides with the interwar period, 1924-1941. The concept "woman" at this period is equal to the concept „worker". The life priority is given to manufacture and public life.

In the course of time, the sense of national festival increased, although the work, shown in newspapers and magazines, was in fact the variety of primitive physical work and was not worth such an inadequate emotional and psychic reaction. By the way, this contradiction was re-

\footnotetext{
3 Druck - kalektyuny agitatar $i$ arganizatar pracounych mas u sacyjalistycznym budaunictwe, „Bielaruskaja Rabotnitsa i Syalyanka” (dalej: BRiS) 1930, nr 12, s. 12.

4 Peryjadyczny druk Bielarusi..., op. cit., s. 19.

5 R.I. Mjeljaszewicz, „Bielaruskaja Rabotnitsa i Syalyanka” - perszaje nacyjanalnaje wydanne dlja żanczyn, „Wiesci BDPU” seria 4, 2005, nr 2, s. 130.

6 Ibidem.

$7 \quad Z$ adozwy CK partyji da rabotnits, syalyanak i pracounych żanczyn Belarusji, BRiS 1928 , nr 12 , s. 5 .
} 
flected on the heroines' faces in the national magazine for Byelorussian women: their true readiness to enthusiastically build a new life ${ }^{8}$.

During the period under research, the topic of struggle for gender equality was one of the leading in the periodical press. Articles, remarks and reports on this topic were published under the special columns, such as „A female-worker in industry”, „International situation”, „The Party's life" ${ }^{\prime}$ etc. The materials were published about the results of the Party and the Soviet authorities' activity in Belarus and women's participation in them, about women clubs creation, preparation for the Russian women congress, about the events, held by women units.

During the whole period under research, since 1926 the material, devoted to engagement of women into social and political activity of the Byelorussian Soviet Socialist Republic [BSSR], was actively published. For example, the article Women take part in reelection of village Soviets was written, based on the talk with a member of the Central Election Committee Samahvalava, where it is declared about the importance of women's participation at the elections of village Soviets ${ }^{10}$.

In 1929 from 14 to 16 of April the Byelorussian Meeting of communist women, working in industry, was held. Apart from different issues, connected with discipline, education, cultural work among the masses and international education, there was a task to recruit female workers for the Party ${ }^{11}$.

The tendency of agitation and engagement of active women into social and political life is vividly traced during the whole period from 1924 to 1939, that is indicated in the articles Work among female workers is the most important task of labor unions ${ }^{12}$, To actively initiate the mass work among female workers and peasants ${ }^{13}$, The participation of

\footnotetext{
R.I. Mjeljaszewicz, op. cit., s. 130.

9 Rabotnitsa $w$ proizwodstwe, Meżdunarodnoe polożenie, Partijinaja żizn, BRiS 1928, nr 2.

10 Żensczciny na perewybory selsowetow, BRiS 1926, nr 12, s. 7.

11 Czto skazalo wsebeloruskoe soweczszanie rabotnits-komunistok, BRiS 1929, $\mathrm{nr} 11$, s. 3-4.

12 Rabota sredi rabotnits - ważnejiscaja zadacza profsojuzow, „Rabotnitsa i Kalhasnica Bielarusi" (dalej: RiKB)1931, nr 15, s. 5.

13 Pa bajawomu razgarnucj masawuju rabotu sjarod rabotnits $i$ syalyanak, RiKB 1931, nr 13, s. 2.
} 
female workers in the Soviet building ${ }^{14}$, About the meeting of the village soviets heads ${ }^{15}$, The meeting of women-members of the government ${ }^{16}$.

The article issued in 1938 is of interest: A woman should be engaged in management. Female staff is disregarded. Earlier on the front pages of the magazine there was a material about the importance and necessity of engagement of women in elections, about the submission of women candidacies to cultural sector and so on. This article is about the problem of appointment of women to managerial jobs:

There isn't any woman - head of the District Executive Committee - in our Republic. There were few heads of village Soviets. 9,6\% was selected in 1934. As on 1 July, 1937 there was not even this amount. Now, according to incomplete statistics of the Central Executive Committee, there were only 116 working women or $7,2 \%$. Within the period of year and a half 25 women heads of village Soviets were dismissed and it means that the authorities on the local level go so far when dealing with this issue, and underestimation and direct disregard of women staff have nothing common with the programme of Lenin and Stalin Party, which considers a Soviet woman to have a great potential for creative work ${ }^{17}$.

A considerable part of the articles was devoted to women's personal stories. In the end of 1920s - beginning of 1930s the life of female workers of factories, cultural sector, women collective farmers etc. was illustrated, but in the end of 1930 s there is a woman-sniper ${ }^{18}$, pilot and parashutist ${ }^{19}$ in the centre of attention. It's directly connected with international situation, with strengthening of aggressive foreign policy of Nazi Germany.

The edition itself carried out an economic and political campaign. This process is vividly shown on the magazine's pages Let's succeed in

14 Udzel pracounych żanczyn u saweckim budaunictwe, RiKB 1932, nr 7, s. 12.

15 Ab naradze starscyn selsawetau, RiKB 1935, nr 14, s. 2.

16 Narada żanczyn - czlenau urada, RiKB 1936, nr 4, s. 13.

17 Żanczynu - na kirujuczuju rabotu. Ignarujucjżanoczyja kadry, RiKB 1938, nr 13, s. 10.

18 Snajper, RiKB 1938, nr 7, s. 5.

19 Stralok, paraszutystka, letczyk, RiKB 1939, nr 15, s. 15. 
bread harvesting ${ }^{20}$, The development of socialist cattle-breading is our operational mission ${ }^{21}$, Flax is in safe hands ${ }^{22}$ etc.

One of the key roles in the fulfilment of social and economic component concerning social competitions, financial plans, production quality etc. was played by active female workers:

It's necessary to absolutely eliminate the gaps in industrial financial plan fulfilment, to actively struggle for the increase of production quality and the decrease of production costs, to inform every worker on the plan. A female worker is involved in the fulfilment of this mission by improving social competition, involvement of new groups of workers into shock brigades (udarniki) ${ }^{23}$.

In the same way in 1931 there were articles like: Let's struggle for carrying out a proclamation of the Central Committee of Communist Party of Bolsheviks in Belarus and the Council of People's Commissars of the BSSR etc. And because of the administrative management structure, the BSSR faced the difficulties which the Soviet economics experienced in total. The productivity remained behind the established rates, the production cost was still high. A serious problem was the production of defective and of poor quality goods. One of the reasons for that was a low qualification of female workers according to the article The instruction of the Central Committee of Communist Party of Bolsheviks in Belarus on the qualification of female workers must be fulfilled:

The qualification of female workers is extremely low, and many women coming to industry are not only properly qualified, but most of them have never worked in industry. It means that the flow of new female workers reduces the amount of qualified women labour force in industry as well as it weakens the proletarian discipline in industry that can get in the way of the development of industry and its implementation ${ }^{24}$.

Here is also given a solution to this problem through the training of qualified staff in professional and technical schools, factory schools

\footnotetext{
20 Zabjaspeczym peramogu u chlebazagatoukach, RiKB 1931, nr 22, s. 3.

21 Razwicje sacyjalistycznaji żyvelagadouli-bajavaja zadacza, RiKB 1931, nr 23, s. 1.

22 Len u nadzejinych rukach, RiKB 1936, nr 15, s. 12-13.

23 Ad XV da XVI zjezdu, BRiS 1930, nr 18, s. 1.

24 Kwalifikacyja rabotnits - neadkladnaja zadacza, BRiS 1930, nr 8, s. 3.
} 
where the percent of women should be not less than $40 \%$ of the total amount of students ${ }^{25}$.

It is necessary to note that the low qualification of female workers and as a result, low quality goods, were due to the illiteracy which people tried to overcome in 1920s, also through active propaganda on the pages of the magazine.

Social and economic changes as an act of building socialist society in the USSR as a whole and the BSSR in particular, implementation of industrialization policy and carrying out a compulsory and rapid collectivization, directly influenced life conditions. In this way, with the help of mass media it was necessary to inform people on the reasons of the established situation and to find ways to solve it. Thus, the article Why do we need the economy mode? dated 1926 to some extend justifies the Republic government policy of strict economy in every possible way and first of all the policy of improvement of the administrative apparatus ${ }^{26}$.

The information about the way, how the policy of collectivization and industrialization was carried out, was given to the readers through the publication of letters which were sent to the editor's office of the magazine „Bielaruskaja Rabotnitsa i Syalyanka”. In the appeal of the woman Yuchkova from Propojsky district there is information about active women's position in the organisation of collective farms (kolkhoz):

Men often used to say before, that their wives don't want to go to kolkhoz, so may they follow us now. We realized that collectivization is an easy way to the socialism and that only in collective farms the status of a working woman will get better ${ }^{27}$.

The sallies of class enemy take place here in the column of the readers' letters. So in 1 May, 1931 an anonymous letter was found on the doors of the village soviet with the following content: In kolkhoz property is common as well as husbands, that is why women don't want to go to kolkhoz. As a result, the delegates kolkhoz meeting named by Apansky identified the person who had written this letter - a citizen Orlova - and stated, that the Orlova's sally is a vivid example of naughty opposition of

\footnotetext{
25 Ibidem.

26 Zaczem nużen reżym ekonomii, BRiS 1926, nr 11, s. 1.

27 Wykanana Dyrektyva partyi. BSSR kalektywizawana da vjasny bolczs czym na $30 \%$, RiKB 1931, nr 15, s. 2.
} 
the kulaks against the kolkhozniks. As a result, the citizen Orlova was brought to justice ${ }^{28}$.

The main method of "socialism building” was strengthening of the repression policy, that couldn't but be reflected on the magazine pages. The example of it was in the headings of the articles For betrayal of socialist motherland - extreme penalty, which revealed the activity of the organizers of trotskist-zinovyev block of Zinovyev, Evdokimov, Smirnov, Bakaev, Mrachkovskij, Ter-Vaganyan, Goltsman, etc. - a foul gang, which prepared an assassination of the workers' leader, a great Stalin and his honourable companions ${ }^{29}$, as well as An extreme control of the Party staff ${ }^{30}$ etc.

As for the security of women in industry and in common life, several important articles about it were noted on the magazine pages.

Much attention is paid to preventive measures against abortion, increase of welfare of pregnant women, establishment of government assistance for the families with many children, increase of the amount of maternity hospitals, nurseries and kindergartens, strengthening of conviction for not paying alimony and some changes in legislation about divorces.

So, the article Give birth to children in maternity hospitals presents arguments for the qualified medical care to mother and child, saying that before the October Revolution... there was an ignorant dirty midwife, who didn't know how to correctly assist in a childbirth... as a result of this ignorance a woman in childbirth paid the price of her life $e^{31}$. Then it is said that in the maternity hospital a woman is provided all the service which is needed during a childbirth: there is everything at hand - a clean bed and cloth, proper medicine, a nurse and a doctor ${ }^{32}$.

The cases of not paying alimony are revealed as well as the treatment of these cases in the BSSR Public Prosecutor's Office. In the preamble of the article it is said that because of the growth of workers' cultural and financial welfare the Soviet Family is growing and getting stronger. But there are cases, when children are abandoned and alimony is not

\footnotetext{
28 Ibidem.

29 Za zdradusacyjalistycznaji Radzime - vycszejicszaja mera pakarannja, RiKB 1936, nr 17 , s. 2 .

30 Bajavaja praverka partyjinych kadrau, RiKB 1938, nr 35/36, s. 1-3.

31 Radżajice u radzilnym dome ci balnicy, RiKB 1935, nr 19, s. 14.

32 Ibidem.
} 
paid. Moreover, the Public Prosecutor's Office was not acting at all. According to the author's point of view, the reason for that, as in many cases, is the result of that system of work in the BSSR Prosecutor's offices, which was spread by the enemies ${ }^{33}$. It is 1937 when the repression policy of the USSR authorities reached a peak.

Military rhetoric and defensive potential of the country are traced during the whole period under research since the first edition of the magazine till 1939. „A foreign enemy” only changed. So the beginning of the article dated 1928 Through the socialist building we'll strengthen the defensive potential of the country is devoted to the celebration of the $8^{\text {th }}$ anniversary of liberation of Belarus from the Polish legionnaires (belopoliaki), then the image of enemy is presented - there are heavily-armed and more and more armed capitalist countries around us. Poland seems to outdo all of us and is clanking with weapons. Therefore, to be able to push the enemy back it is necessary to accumulate all the forces for the building of socialism ${ }^{34}$. Before 1930s the anti-polish rhetoric used to remain ${ }^{35}$.

To 1938-1939 due to the international events the attention is drawn from the Polish and Soviet issues to the First World War as the cause of extreme tension, feverish preparation of fascist aggressors and their supporters for the new world war ${ }^{36}$. A separate column appears The whole nation will go to defend the country. Therefore, an appeal to actively build the defensive potential of the country goes through all the headings of the articles Let us transform a factory into a defence fortress ${ }^{37}$, Let us teach a lesson to Samurais ${ }^{38}$, If the war is tomorrow ${ }^{39}$, The force of war and the force of piece ${ }^{40}$ and so on.

There is a great interest in the selection of editions dated 1939 from September - the beginning of the First World War. So, №17 of 1939 starts from the slogan May the workers' and peasants' Red Army and the Navy exist that is the invincible strength of the socialist country! Here

\footnotetext{
${ }_{33}$ Ja adnosjaca da alimentnyh sprau u prakuratury respubliki, RiKB 1937, nr 19, s. 16.

34 Socialisticzeskim stroitelstwom-ukrepim oboronosposobnostj strany, BRiS 1928, nr 7, s. 1.

${ }^{35}$ List da rabotnits i pracounych syalyanak Zachodnjaji Belarusi, RiKB 1931, nr 7, s. 1.

36 Front wajiny i front miru, RiKB 1938, nr 14, s. 12.

37 Preobrazuem zavod v krepostj oborony, RiKB 1938, nr 15, s. 2.

38 Prawuczym samurajau, RiKB 1938, nr 15, s. 2.

39 Kali zautra vajina, RiKB 1938, nr 15, s. 2.

40 Sila vajina i sila miru, RiKB 1939, nr 14, s. 13.
} 
there is also a V. Molotov's message about the ratification of the Soviet and German non-aggression pact, where the foreign policy reasons for it are explained. One of such reasons is the unwillingness of Great Britain and France to reach an agreement in terms of the principle of mutuality and equality of duties ${ }^{41}$.

The next edition is devoted to "the historical decision" - on the entrance of the Red Army in the territory of West Belarus and West Ukraine. The speech of the head of the USSR Council of People's Commissars V. Molotov was published. He says: the Polish and German War revealed the inner failure of the Polish country ${ }^{42}$. Due to this, the Soviet government can't stand aside from the destinies of its natives, Ukrainians and Belarusians, who live in Poland and used to be a nation without civil rights ${ }^{43}$. In edition 21 there was a law about the inclusion of West Belarus into the USSR in the process of joining the BSSR ${ }^{44}$.

Thus, examined the illustration of social and political processes on the pages of the women press, in particular, of monthly magazine „Bielaruskaja Rabotnitsa i Syalyanka”, within the period under research it can be noted that printed press showed a vivid reaction to various problems which concern the engagement of women into social and political development of the BSSR, as well as into industrial work, an increase of women's role in agricultural production. These issues were illustrated in direct connection with the total social and economic and social and political situation in the USSR as whole and in the BSSR in particular.

It is necessary to note that in the beginning the magazine „Bielaruskaja Rabotnitsa i Syalyanka” published the materials only for women, for example healthcare and sports, recipes, mother and child, etc., but in 1930s the situation changed towards the politicization and the ideologization of the magazine itself, it started to be an information guide between the Soviet country and the BSSR women.

\footnotetext{
${ }^{41}$ Ab ratyfikacyi sawecka-germanskaga dagavora ab nenapadze, RiKB 1939, nr 17, s. 2.

42 Gistarycznaje rachenne. Pramova pa radyje starchsyni SNK BSSR taw. Molatawa, RiKB 1939, nr 18, s. 4.

43 Ibidem, s. 5.

44 Ab znechsnjaji palitycy SSSR, RiKB 1939, nr 21, s. 4.
} 


\section{Bibliografia}

\section{Źródła}

Ab naradze starscyn selsawetau, „Rabotnitsa i Kalhasnica Bielarusi” 1935, nr 14, s. 2.

Ab ratyfikacyi sawecka-germanskaga dagavora ab nenapadze, „Rabotnitsa i Kalhasnica Bielarusi" 1939, nr 17, s. 2.

Ab znechsnjaji palitycy SSSR, „Rabotnitsa i Kalhasnica Bielarusi” 1939, nr 21, s. 4.

Ad XV da XVI zjezdu, „Bielaruskaja Rabotnitsa i Syalyanka” 1930, nr 18, s. 1.

Bajavaja praverka partyjinych kadrau, „Rabotnitsa i Kalhasnica Bielarusi” 1938, nr 35/36, s. 1-3.

Czto skazalo wsebeloruskoe soweczszanie rabotnits-komunistok, „Bielaruskaja Rabotnitsa i Syalyanka" 1929, nr 11, s. 3-4.

Druck - kalektyuny agitatar $i$ arganizatar pracounych mas $u$ sacyjalistycznym budaunictwe, „Bielaruskaja Rabotnitsa i Syalyanka” 1930, nr 12, s. 12.

Front wajiny i front miru, „Rabotnitsa i Kalhasnica Bielarusi” 1938, nr 14, s. 12.

Gistarycznaje rachenne. Pramova pa radyje starchsyni SNK BSSR taw. Molatawa, „Rabotnitsa i Kalhasnica Bielarusi” 1939, nr 18, s. 4.

Ja adnosjaca da alimentnyh sprau u prakuratury respubliki, „Rabotnitsa i Kalhasnica Bielarusi" 1937, nr 19, s. 16.

Kali zautra vajina, „Rabotnitsa i Kalhasnica Bielarusi” 1938, nr 15, s. 2.

Kwalifikacyja rabotnits - neadkladnaja zadacza, „Bielaruskaja Rabotnitsa i Syalyanka" 1930, nr 8, s. 3.

Len u nadzejinych rukach, „Rabotnitsa i Kalhasnica Bielarusi” 1936, nr 15, s. $12-13$.

List da rabotnits b pracounych syalyanak Zachodnjaji Belarusi, „Rabotnitsa i Kalhasnica Bielarusi” 1931, nr 7, s. 1.

Narada żanczyn - czlenau urada, „Rabotnitsa i Kalhasnica Bielarusi” 1936, nr 4, s. 13.

Pa bajawomu razgarnucj masawuju rabotu sjarod rabotnits $i$ syalyanak, „Rabotnitsa i Kalhasnica Bielarusi” 1931, nr 13, s. 2. 
Prawuczym samurajau, „Rabotnitsa i Kalhasnica Bielarusi” 1938, nr 15, s. 2.

Preobrazuem zavod v krepostj oborony, „Rabotnitsa i Kalhasnica Bielarusi” 1938, nr 15, s. 2.

Rabota sredi rabotnits - ważnejiscaja zadacza profsojuzow, „Rabotnitsa i Kalhasnica Bielarusi" 1931, nr 15, s. 5.

Rabotnitsa w proizwodstwe, Meżdunarodnoe polożenie, Partijinaja żizn, „Bielaruskaja Rabotnitsa i Syalyanka" 1928, nr 2.

Radżajice u radzilnym dome ci balnicy, „Rabotnitsa i Kalhasnica Bielarusi” 1935, nr 19, s. 14.

Razwicje sacyjalistycznaji żyvelagadouli - bajavaja zadacza, „Rabotnitsa i Kalhasnica Bielarusi” 1931, nr 23, s. 1.

Sila vajina i sila miru, „Rabotnitsa i Kalhasnica Bielarusi” 1939, nr 14, s. 13. Snajper, „Rabotnitsa i Kalhasnica Bielarusi” 1938, nr 7, s. 5.

Socialisticzeskim stroitelstwom - ukrepim oboronosposobnostj strany, „Bielaruskaja Rabotnitsa i Syalyanka” 1928, nr 7, s. 1.

Stralok, paraszutystka, letczyk, „Rabotnitsa i Kalhasnica Bielarusi” 1939, nr 15, s. 15.

U boj za ażyccjaulenne adozvy CK KP(b)B i SNK BSSR, „Rabotnitsa i Kalhasnica Bielarusi" 1931, nr 5, s. 1.

Udzel pracounych żanczyn u saweckim budaunictwe, „Rabotnitsa i Kalhasnica Bielarusi" 1932, nr 7, s. 12.

Wykanana Dyrektyva partyi. BSSR kalektywizawana da vjasny bolczs czym na 30\%, „Rabotnitsa i Kalhasnica Bielarusi” 1931, nr 15, s. 2.

$Z$ adozwy CK partyji da rabotnits, syalyanak i pracounych żanczyn Belarusii, „Bielaruskaja Rabotnitsa i Syalyanka” 1928, nr 12, s. 5.

Za zdradusacyjalistycznaji Radzime - vycszejicszaja mera pakarannja, „Rabotnitsa i Kalhasnica Bielarusi" 1936, nr 17, s. 2.

Zabjaspeczym peramogu u chlebazagatoukach, „Rabotnitsa i Kalhasnica Bielarusi" 1931, nr 22, s. 3.

Zaczem nużen reżym ekonomii, „Bielaruskaja Rabotnitsa i Syalyanka” 1926, nr 11, s. 1.

Żanczynu - na kirujuczuju rabotu. Ignarujucj żanoczyja kadry, „Rabotnitsa i Kalhasnica Bielarusi" 1938, nr 13, s. 10.

Żensczciny na perewybory selsowetow, „Bielaruskaja Rabotnitsa i Syalyanka" 1926, nr 12, s. 7. 


\section{Opracowania}

Kostenko, J.A., Żenskoje dviżenije w Rossiji w 1920-1930 gg. Avtoreferat na soiskanije stepeni kandidata istoricheskih nauk, Moskwa 2006, s. 22-23.

Mjeljaszewicz, R.I., „Bielaruskaja Rabotnitsa i Syalyanka” - perszaje nacyjanalnaje wydanne dlja żanczyn, „Wiesci BDPU” seria 4, 2005, nr 2, s. 130, ISSN 1818-8583.

Peryjadyczny druk Biełarusi, red. W.S. Adamowicz [et. al.] [w:] Bielaruskaja sawetskaja encyklapedyja, Minsk 1981, s. 19. 